\title{
“A River as a Character" (2019)
}

\author{
Catherine Gough-Brady \\ RMIT University School of Media and Communication, Melbourne, Australia \\ catherine.gough-brady@snodger.com.au
}

\begin{abstract}
As a filmmaker, the author felt the need to develop a deep connection with her subject, but was unsure how to do so with the Murray-Darling River. Initially, she saw the river as a system akin to what Pierre Bourdieu calls a field: forces external to the author acting upon each other. She felt that to connect with the river she needed to adjust her habitus (personal dispositions; way of being) to its field. This continued once the author returned to Melbourne, but through the medium of the images of the river. During the edit, she shifted from seeing the river as a field of external forces to seeing it as a habitus, a way of being. This was necessary for the river to become a character, rather than just a location.
\end{abstract}

\section{Keywords}

character - Murray-Darling River - Bourdieu - habitus - non-representational theory - digital paper 


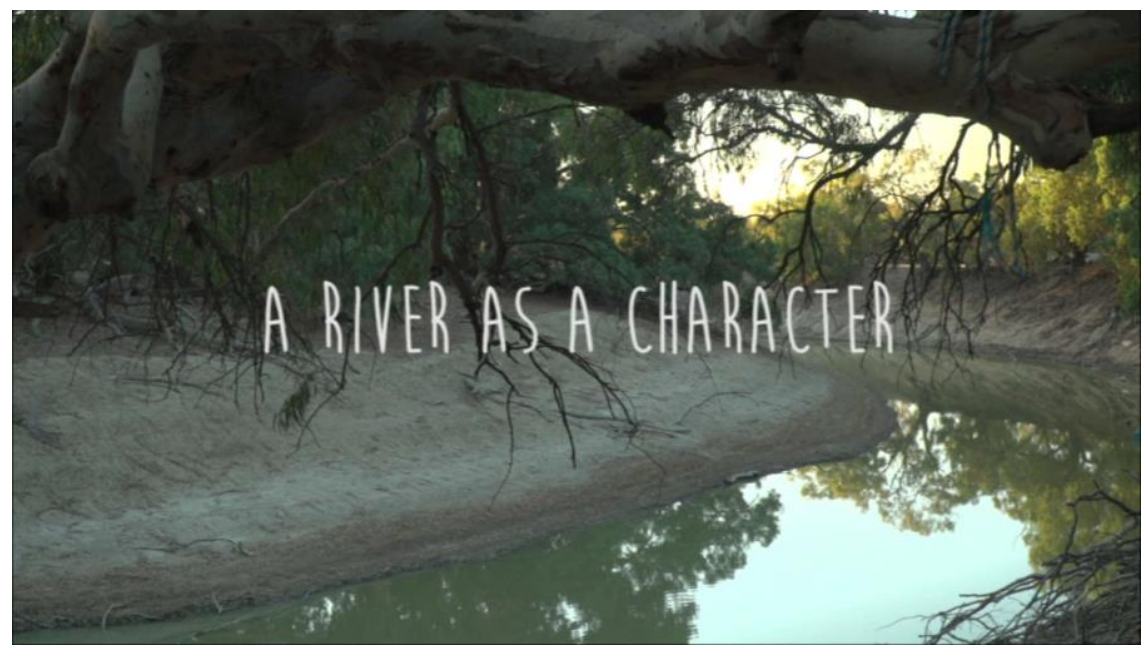

FEATURE Catherine Gough-Brady's article is based on the film 'A River as a Character' which can be viewed here.

\section{Accompanying Film}

Title: "A River as a Character"

Year of release: 2019

Duration: 9:13

URL: https://vimeo.com/352592769

\section{$2 \quad$ A Digital Paper}

Digital papers grew out of my desire to use my art medium (audio-visual) to communicate academic research to an audience. The digital papers are neither traditional academic essays, nor are they traditional documentaries. They have emerged from the intersection of my film and TV industry practice with academic research. This intersection has resulted in works that are a subset of essay films: ${ }^{1} \mathrm{I}$ have created an 'essayist author' who is the storyteller and reveals reflections, theory and explication. My intention is that the author will not explain everything, as Laura Rascaroli writes, "The essayist does not

\footnotetext{
${ }^{1}$ Laura Rascaroli writes about the nature of the essay film: "Most of the existing scholarly contributions acknowledge that the definition of essay film is challenging, and suggest that it is a hybrid form, which crosses boundaries and rests somewhere in between fiction and nonfiction cinema." (2009, p. 21).
} 
pretend to discover truths to which he holds the key but allows the answers to emerge somewhere else, precisely in the position occupied by the embodied spectator" (2009, p. 36).

The digital papers disrupt modes of academic writing by using audio-visual media, which has different affordances than text. Education theorist Margaret Somerville discusses how transgressive or disruptive forms effect the production of meaning and make it "dynamic and constituted intertextually between the various elements of the performance or representation" (2007, p. 239). In the digital papers meaning is formed differently because film is better able to convey things such as "the body language of an interviewee" or the "façade of a building" (Sørensen \& Eriksson, 2012, p. 7). What is implicit in text can become explicit in video, and vice versa. For instance, the argument put forward in my digital papers meanders, rather than drives forward: the viewer can miss theoretical points as they instead watch imagery, or tune out to think about an idea raised, just as they would when watching a documentary. While I do have what Umberto Eco calls a 'model reader' (1992) in mind when I create the works, different viewers will find slightly different meanings, some of which I intend, but others that I had not even noticed. This creates the opportunity for a dialogue in which meaning is constantly growing and adapting. I see my role, as the 'author', as creating the space in which this meaning can be formed in collaboration with the viewer.

For further discussion on digital papers please refer to my report in Alphaville, "The methodology behind digital papers" (2019).

\section{Statement to Accompany the Film}

This digital paper explores the creation of a short experimental film, River Crisis (2019), that I made as part of my PhD. In River Crisis, I asked: can I create a central character out of a river system? I decided that there would be no human voices or stories in this film, this would allow space for the river to be the principal character of the film. This research developed earlier work in which I explored the effect on the creative process of not having a central character (see Expect Delays, 2018).

Feminist theorist Sara Ahmed writes that character "is an idea of consistency" (2001, p. 231): "Not to fulfil an expectation of character is to be out of character; but to be out of character is to be understood in relation to an expectation of character, however unfulfilled" (2001, p. 231). As Ahmed suggests, a character has a set of expected values. To create a character from a

VIDEO JOURNAL OF EDUCATION AND PEDAGOGY (2019) 1-8 
river system, I needed to develop an understanding of the character of a river, essentially the values and actions of a river.

There is a belief in fiction theory and in documentary practice that character "is revealed in the choices a human being makes under pressure" (McKee, 1999, p. 101). Documentarians often choose to film a person at a point of crisis, and true to form, I filmed the river when it was "under pressure." The Murray section of the river system contained more water than it naturally would during the summer months, this was to ensure the irrigators had sufficient water for their crops. The Darling section of the river had the opposite problem: a lack of water caused it to stop flowing. I dispute McKee's statement that pressure reveals true character; instead, I argue, with Ahmed (2001), that character is a result of consistency, and consistency is not just found in the actions of a person, but also in the consistency in their experience. The character of the river was not revealed by too much or too little water, instead it was changed.

Another example of subjects under pressure can be found in Journey Beyond Fear (2018), where Robyn Hughan filmed a refugee family from Afghanistan/Iran living in precarious and powerless conditions in Kuala Lumpur. They suffered from depression as a result. And yet, "the family blossoms" once they are no longer experiencing these precarious conditions (Hughan, n.d.). Their personalities change as their stress-related depression lifts. Extreme pressure over time, or the lack of extreme pressure, changes the nature of that character rather than necessarily reveals character. For the river, the extreme pressures it experiences are climate change, especially the effects of drought, and current water management practices.

Given that character is impacted by environmental conditions, it is important to examine character in relationship to that environment. Pierre Bourdieu compares his notion of habitus to character: "the habitus, as the Latin indicates, is something non-natural, a set of acquired characteristics which are the product of social conditions and which, for that reason may be totally or partially common to people who have seen the product of similar conditions" (2002, p. 29). Habitus and character both change depending upon external social conditions. My own habitus is that of an urban middle-class woman from the arts field, who is very much a part of Melbourne. I had limited experience of river systems: for me water drips out of a tap, food is found on supermarket shelves, and nature is something tamed in nearby parks. I felt that my habitus was not acclimatised to, nor directly formed by, experience of the 'field' of the river system.

As a documentarian I feel the need to acclimatise to the field in which I film. The reason I need to understand, say, the river system field, is because my

VIDEO JOURNAL OF EDUCATION AND PEDAGOGY (2019) $\quad$ 1-8 
intention is to create a film that communicates the character of the river to an audience. I act as a conduit between the viewer and the what I film, and this informs my pedagogy, which is predicated on an idea of sharing a sense of direct experience. Given character and habitus are the result of social conditions, to understand the character I need to understand their field. If I did not find a connection with the river system, then how could I expect a viewer to find one? Non-representational theorist Tim Ingold explains this well: "Telling a story is not like weaving a tapestry to cover up the world, it is rather a way of guiding the attention of listeners or readers into it" (1993, p. 153). I initially saw my desire to align my habitus with the field as a way of aligning my inner self or habitus with the outer world or field of the river system. As much as I intended to create a character out of the river, I still saw it as an environment, or a field, rather than a character.

The relational quality of documentary I experience is not just with people or things in the pro-filmic world (what takes place in front of the lens), it is also with the images captured in the frame. When Jane Bennet writes about the enchantment of the material, she starts "from the assumption that the world has become neither inert nor devoid of surprise but continues to inspire deep and powerful attachments" (2001, p. 4). The video images of the river are not inert: they inspire me, surprise me, and are in a fluid state as they become a part of the edit. The process of creating characters from things filmed is a process of developing a relationship with the images, where those images (separate from the thing they depict) have agency. The images direct my edit choices; for instance, the moment when I decided to use the camera shakes as a way of revealing the presence of the cameraperson was in response to the images. $^{2}$

Over the course of the edit, I realised that to successfully create a character from the river system I needed to stop seeing it as a field and see it as a habitus. For me, creating a character out of landscape required that I thought about it as an entity, rather than "a space of forces or determinations" (Bourdieu 2002, p. 31). Filmmaker and academic Karen Pearlman suggests that editing requires the alignment of "editor's living, breathing body" (2009, p.15) with the material being edited, usually another body with its own breath and rhythms. In this case I was forming an alignment with a river system, finding the entity's breath in, for instance, the wind, or their movement in the flight of the birds etc. This was part of my process of finding a connection: through relating to the images 'we' came to communicate 'habitus to habitus'. I had made the river into a

\footnotetext{
${ }^{2}$ Here I just speak about the images, not the audio, because the audio was entirely constructed by Kyle Barbour-Hoffman and Mitchell Waters.
}

VIDEO JOURNAL OF EDUCATION AND PEDAGOGY (2O19) $\quad$ 1-8 
body-like thing with which I could rhythmically link, two entities communicating with each other.

\section{$4 \quad$ Software}

I used a Sony $\mathrm{FS}_{5}$ with a Manfrotto tripod, a home-made periscope, a Zoom $\mathrm{H} 4 \mathrm{n}$ with a Rycote handhold to record the footage. I edited on Adobe Premiere Pro.

\section{$5 \quad$ Re-editing}

I have the capacity to re-edit the digital paper and welcome constructive feedback. But I do have two conditions. Firstly, I will not re-edit the three segments of the River Crisis excerpts, they contain an integrated sound design and to edit into them would interfere with that sound design. Secondly, please note that this is a digital paper: a form of essay film that includes academic theory, explication and reflection. Please see section 2 for a discussion on the nature of the digital paper.

\section{$6 \quad$ Copyright}

Please note that all copyright in this film is owned by Catherine Gough-Brady. Please note this copyright is not creative commons.

\section{$7 \quad$ Ethics}

I am the only person who appears in this film. I have ethics clearance from RMIT University to film documentary filmmakers talking about the process of creating documentary films. As I am a documentary filmmaker, so this clearance includes myself. No high risk conversations took place. The river is unable to give consent, nonetheless, I received permits to film in all the locations from the NSW and Victoria governments. On privately owned locations I had permission to access the private properties from the owners of the properties. 


\section{$8 \quad$ Digital Paper Credits}

Filmmaker

Catherine Gough-Brady

Sound Design of River Crisis (2019)

Kyle Barbour-Hoffman

Mitchell Waters

\section{Acknowledgements}

Catherine Gough-Brady is a $\mathrm{PhD}$ student at RMIT University and a recipient of an Australian Government Research Training Program Scholarship. Thanks to the DERC video team for their feedback on drafts of this digital paper, especially Christine Rogers and Jayne White. Thanks to my supervisory team: Craig Batty, Leo Berkeley and Marsha Berry.

\section{References}

Ahmed, S. (2011). Willful Parts: Problem Characters or the Problem of Character. New Literary History, 42(2), 231-253. Retrieved from http://www.jstor.org.ezproxy.lib.rmit.edu.au/stable/23012542.

Bennett, J. (2001). The Enchantment of Modern Life: Attachments, Crossings, and Ethics. Princeton, USA: Princeton University Press.

Bourdieu, P., \& Johnson, R. (1993). The Field of Cultural Production: Essays on Art and Literature. Columbia University Press.

Bourdieu, P. (2002). Habitus. In J. Hillier \& E. Rooksby (Eds.), Habitus: A Sense of Place (pp. 27-34). Aldershot: Ashgate.

Eco, U. (1992). Reading My Readers. MLN, 107(5), 819-827. doi:10.2307/2904818.

Gershon, I., \& Malitsky, J. (2010). Actor-network theory and documentary studies. Studies in Documentary Film, 4(1), 65-78. doi:10.1386/sdf.4.1.65_1.

Gough-Brady, C. (Director). (2018). Expect Delays.

Gough-Brady, C. (Director). (2019). River Crisis.

Gough-Brady, C. (2019). The Methodology behind Digital Papers. Alphaville:Journal of Film and Screen Media, (17), 179-187. doi:10.33178/alpha.17.12.

Hughan, R. (Director). (2018). Journey Beyond Fear.

Hughan, R. (n.d.) About. Retrieved from https://www.journeybeyondfear.com/partners. 
Ingold, T. (1993). The Temporality of the Landscape. World Archaeology, 25(2), 152-174. Retrieved from http://www.jstor.org.ezproxy.lib.rmit.edu.au/stable/124811.

McKee, R. (1999). Story: Substance, structure, style, and the principles of screenwriting. London: Methuen.

Rascaroli, L. (2009). The Personal Camera: subjective cinema and the essay film. New York: Wallflower Press.

Somerville, M. (2007). Postmodern emergence. International Journal of Qualitative Studies in Education, 2o(2), 225-243. doi:10.1080/0951839o6o115975o.

Sørensen, I., \& Eriksson, T. (2012). Reflections on academic video. Seminar.net, 8(1). 